\title{
Frequent attenders to emergency department in a research hospital in Turkey
}

\section{Türkiye'de bir araştırma hastanesinde acil servise sık başvuru nedenleri}

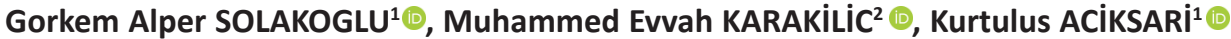

\section{ABSTRACT}

Aim: Frequent attenders to emergency departments have become an increasingly important healthcare problem in the whole world. In our study we aimed to define characteristics of this frail population with their own unique problems.

Method: Study was conducted in Ankara Numune Training and Research Hospital during a 1-year period between 01.01.2013 and 01.12.2013 with adult patients older than 18 years old who made emergency visits more than 12 times a year were included in the study. Each patient's demographic data (age, sex, marital status), medical insurance status, cause of death, residential address, chronic disorders were noted and included in evaluations.

Results: A total of 169,066 emergency department visits done by 124,574 different patients were detected. Hundred and seventeen frequent attenders (76 men, and 41 women) visited emergency departments for a total of 2,162 times. The number of visits ranged from 12 to 91 per year. Of them the uninsured patients were significantly older. Both the age and number (\%) of divorced/widowed patients were significantly higher compared to other groups $(p<0.05)$. Pain was significantly the most common presenting symptom followed by psychiatric complaints. Frequent attenders had mostly psychiatric and chronic painful diseases in general but patients with hematological disorders had visited emergency services significantly more frequently compared with the patients with other chronic diseases.Sixteen patients died during the study period. It was demonstrated that the deceased patients had applied to emergency services more frequently, and they had significantly higher mean age, and significantly higher rates of chronic internal and oncological disorders.

Conclusion: The patients who visited emergency services frequently belonged to a frail population with complex problems. The solution of these problems should priorly be possible with recognition of characteristic features of this patient population. öz

Amaç: Acil servislere yineleyen başvurusu olan hastalar, dünya çapında önemli bir sağlık sorunu haline gelmiştir. Çalışmamızın amacı, kendine özgü problemleriyle kırılgan olan bu hasta popülasyonunun özelliklerini tanımlamaktır.

Yöntem: Çalışmaya 01.01.2013-01.12.2013 tarihleri arasında 1 yıl süre ile Ankara'da bir eğitim ve araştırma hastanesi acil servisine başvurmuş 18 yaş üstü hastalar dahil edildi. Her hastanın demografik verileri (yaş, cinsiyet, medeni durum), sağlık sigortası, ölüm nedeni, yerleşim adresi, kronik rahatsızlıkları kaydedildi ve değerlendirmeye alındı.

Bulgular: 124.566 farklı hasta tarafindan yapılan toplam 169.066 acil servis ziyareti yapıldığı belirlendi. Yüz on yedi mükerrer hastanın toplam 2.162 kez acil servise başvurduğu görüldü. Bu hastaların 76'sı erkek, 41'i kadındı. Başvuru sayıları yılda 12 ile 91 arasında değişmekteydi. Sigortasız hastalar daha yaşlıydı. Boşanmış/ dul olanların yaşı ve mükerrer başvuru sıklığı diğer gruplara göre anlamlı olarak yüksek bulundu $(p<0,05)$. Ağrı, psikiyatrik şikayetleri takiben en sık görülen semptom olarak belirlendi. Bu hasta grubunda psikiyatrik ve ağrılı kronik hastalıklar sıklıkla görülürdü ve hematolojik hastalığı olanların diğer kronik hastalığı olanlara göre daha sık acil servis başvurusunda bulunduğu belirlendi. ÇaIışma süresince 16 hasta öldü. Ölen hastaların acil servise daha sık başvurduğu, yaş ortalamasının yüksek olduğu kronik dahili ve onkolojik hastalıklarının daha sık olduğu gösterildi.

Sonuç: Kırılgan bir popülasyon olan ve acil servise yineleyen başvurularda bulunan hastaların karmaşık sorunları vardır. Bu sorunların çözümü öncelikle bu hasta popülasyonunun karakteristik özelliklerini tanımak ile olası olabilecektir.

Anahtar kelimeler: Acil tıp, sık hastalar, aşırı kalabalık

Received: 23.02 .2018

Accepted: 30.06 .2018

${ }^{1}$ Department of Emergency Medicine, Istanbul Medeniyet University Goztepe Research \& Training Hospital, Istanbul, Turkey

${ }^{2}$ Department of Emergency Medicine, Faculty of Medicine, Eskişehir Osmangazi University, Eskisehir, Turkey

Yazışma adresi: Gorkem Alper Solakoglu, Department of Emergency Medicine, Istanbul Medeniyet University Goztepe Research \& Training Hospital, Istanbul, Turkey

e-mail: gorkemalper.solakoglu@gmail.com

Yazarların ORCiD bilgileri:

G.A.S. 0000-0002-6936-4924, M.E.K. 0000-0003-1414-8914, K.A. 0000-0002-0749-4651 


\section{INTRODUCTION}

Overcrowding of emergency departments is a major public health problem worldwide ${ }^{1}$ referring to a condition whereby the number of emergency visits exceeds the capacity of emergency room and the healthcare staff's limit of delivering an adequate and efficient health care. When this condition persists on a long-term basis, emergency departments are overloaded by a regularly excessive patient volume and continuously work beyond their capacity.

Ninety million emergency department visits occur each year in Turkey, a country with a unique place in the world for providing healthcare to many patients that is greater than its whole population, where overcrowding of emergency department is experienced in its most severe form. Frequent attenders who have lower disease severity scores usually visit emergency departments for non-emergent causes, leave emergency departments on their own free will, and have a lower hospital admission rates compared to one-time attenders. In addition, they visit family physicians more often, and more commonly use community health nursing services, social services, addiction counseling and psychiatric support services, and other departments ${ }^{2,3}$.

In this study, we aimed to define the group of frequent attenders and their characteristics. Thus, the features of emergency department visits of this group of frail patients can be more clearly understood and the information provided by this study can be used to find solutions to reduce the rate of recurrent visits.

\section{MATERIAL and METHOD}

The study center was a reference hospital in Turkey. This study was conducted retrospectively by reviewing case series that frequently visit emergency departments. After approval of the study by the ethics committee, this study retrospectively reviewed all emergency department visits during a 1-year period between 01.01.2013 and 01.12.2013. There is controversy about the definition of frequent attenders in the literature. While some studies have considered having at least two visits within a 1-year period is sufficient for the definition of frequent attenders, the number goes up to at least 12 visits in some others ${ }^{3-6}$. On the other hand, some studies included frequent visits not only within a year, but also within different time frames ${ }^{7,8}$. We defined frequent visits as 12 visits within a period of 1 year and included adult patients aged 18 years or older who visited emergency departments for 12 times or more.

\section{Measurement of Variables}

The primary reason for emergency department visit was considered as admission diagnosis, and additional information regarding chronic disorders were obtained from our hospital's database including each patient's demographic data (age, sex, marital status), medical insurance status (green card is an insurance type which is given to poor and unemployed citizens by government), cause of death, and residential address, with the latter being used to calculate the distance between residential address and the study hospital from Google Maps. All diagnoses were classified according to the ICD classification. Patients were declared dead when they died during the study period while they were considered as alive when they died afterwards.

\section{Statistical Analyses}

Continuous variables were analyzed by analyzing mean, median, and standard deviation while categorical variables using analysis of frequencies. Statistical significance was determined using chi-square, Kruskal-Wallis, and Mann-Whitney $U$ tests as appropriate. A $p<0.05$ was considered statistically significant. All statistical analyses were performed using SPSS v. 15.

\section{RESULTS}

A total of 169,066 emergency department visits were made in the calendar year of 2013 and a total of 124,574 patients visited emergency department during the same period, with the difference between the two figures representing the repeated visits. 
During the same period, patients visited our emergency department for 1 to 4 ( $n=121,828: 97.8 \%)$, $\geq 4(n=2625: 2.1 \%$; total $n=16,784: 9.9 \%)$, and $\geq 12$ ( $n=119: 0.1 \%$, total $n=2,192: 1.3 \%$ ) times.

Of 119 patients , 2 were excluded from the study due to missing medical data, and the remaining 117 patients were included in the study. The age range of these 117 patients was $18-81$ years, with a mean age of $41.5 \pm 15.3$ years and a median age of 41 years. There were $76(65 \%)$ men and 41 (35\%) women in the study.
Thirty-four (29.1\%) patients were single, 22 (18.8\%) were divorced/widowed, and 45 (38.5\%) were married. Six more patients were excluded from the final analysis owing to missing medical data. Twenty-six (26/76:34.2\%) men, and nineteen (19/41:46.3\%) women were married Both the age and frequency of divorced/widowed participants were significantly higher compared to other groups $(p<0.05)$.

Hundred and seventeen patients visited emergency departments for a total of 2,162 times. The interval

Table 1. Distribution of frequent patients by medical insurance status.

\begin{tabular}{llllll}
\hline & Mean repeated visits & Mean frequency & Mean age & Percentage of Men/Women & Percent \\
\hline Green Card & $20.64 \pm 20.5$ & $17 \pm 9.13$ & $42.1 \pm 17.2$ & $\% 94.1$ & $\% 14.5$ \\
Insured & $17 \pm 5.6$ & $15.16 \pm 7.5$ & $42.3 \pm 16.12$ & $\% 46$ & $\% 57.3$ \\
Uninsured & $17.5 \pm 7.8$ & $14.4 \pm 8.5$ & $35.5 \pm 10.8$ & $\% 95.2$ & $\% 17.9$ \\
In need of nursing & $23.5 \pm 16.24$ & $15 \pm 7.4$ & $46.4 \pm 13.3$ & $\% 75$ & $\% 10.3$ \\
\end{tabular}

*One female patient with insurance was excluded owing to being a convict.

Table 2. The most common 15 diagnoses of frequent patients in the emergency department.

\begin{tabular}{|c|c|c|c|}
\hline Admission diagnosis in the emergency department & Number of visits & Number of patients & Percent among total repeated visits \\
\hline Pain-related* & 631 & 76 & 28.7 \\
\hline Psychiatric complaints & 131 & 13 & 5.9 \\
\hline UTI & 130 & 34 & 5.9 \\
\hline Abdominal/Pelvic pain & 102 & 24 & 4.6 \\
\hline Headache & 76 & 14 & 3.4 \\
\hline Anxiety & 72 & 20 & 3.2 \\
\hline Fatigue/Malaise & 62 & 12 & 2.8 \\
\hline COPD/Dyspnea & 60 & 10 & 2.7 \\
\hline General examination & 59 & 15 & 2.6 \\
\hline Urticaria & 50 & 13 & 2.2 \\
\hline Alcohol-related & 46 & 6 & 2.0 \\
\hline Drug withdrawal symptoms & 42 & 4 & 1.9 \\
\hline Simple trauma & 42 & 25 & 1.9 \\
\hline Renal colic & 40 & 5 & 1.8 \\
\hline Vertigo & 38 & 8 & 1.7 \\
\hline \multicolumn{4}{|c|}{ *Includes myalgias, low back pain, chronic disease pain, and chronic peripheral artery disease. } \\
\hline \multicolumn{4}{|c|}{ Supplementary table detailing pain-related diagnoses } \\
\hline Admission diagnosis in the emergency department & Number of visits & Number of patients & Percent among total repeated visits \\
\hline Chronic pain & 280 & 38 & 12.7 \\
\hline Back pain & 167 & 17 & 7.6 \\
\hline Extremity myalgias & 167 & 14 & 7.6 \\
\hline Abdominal/Pelvic pain & 102 & 24 & 4.6 \\
\hline Headache & 76 & 14 & 3.4 \\
\hline Renal colic & 40 & 5 & 1.8 \\
\hline Chronic peripheral artery disease pain & 17 & 2 & 0.7 \\
\hline Total & 849 & 82 & 38.7 \\
\hline
\end{tabular}


between visits ranged between 1 day and 30 days. The mean frequency of visits was $14.6 \pm 7.9$ days, and the number of visits ranged between 12 and 91 (mean 18.28 \pm 10.8 ). The medical insurance status of the patients is summarized in Table 1. Notably, the uninsured patients were significantly older than other groups $(p<0.05)$.
Emergency department visits were also analyzed with respect to time of visit, i.e. between 8.00-17.00 and 17.00-8.00. According to this analysis, among the total number of 2,139 visits, 750 (33.7\%) occurred during night shifts (17.00-8.00) and 1,412 (65.3\%) occurred during day shifts (8.00-17.00). Thirty-seven patients with a chronic psychiatric disorder, who constituted

Table 3. Distribution of the diagnoses for which patients visited emergency department at least once.

\begin{tabular}{|c|c|c|c|c|c|}
\hline & Frequency/Percentage & $\begin{array}{l}\text { M/F } \\
\text { percentage }\end{array}$ & Mean age & $\begin{array}{l}\text { Mean number of } \\
\text { repeated visits }\end{array}$ & $\begin{array}{l}\text { Mean } \\
\text { Frequency }\end{array}$ \\
\hline Infectious diseases & $48(41.0 \%)$ & $\% 56.2$ & $39.2 \pm 14.2$ & $18.7 \pm 12.8$ & $16.3 \pm 8.3$ \\
\hline Psychiatry & $42(35.6 \%)$ & $\% 78.5$ & $40.2 \pm 13.6$ & $19.8 \pm 9.61$ & $15.06 \pm 7.82$ \\
\hline Gastroenterology & $38(32.5 \%)$ & $\% 50$ & $44.5 \pm 16.75$ & $17.5 \pm 7,46$ & $15.2 \pm 7.62$ \\
\hline Physical therapy and rehabilitation / rheumatology & $30(25.6 \%)$ & $\% 73.5$ & $38.2 \pm 13.06$ & $21.3 \pm 16.2$ & $15.4 \pm 8.06$ \\
\hline Neurology & $30(25.6 \%)$ & $\% 60$ & $41.1 \pm 18.06$ & $16.6 \pm 4.45$ & $16.2 \pm 8.29$ \\
\hline Dermatology & $17(14.5 \%)$ & $\% 76.4$ & $41.2 \pm 15.17$ & $19.4 \pm 10.28$ & $11.2 \pm 6.58$ \\
\hline Chest Diseases & $14(12.0 \%)$ & $\% 71.4$ & $44.1 \pm 18.52$ & $16.4 \pm 4.51$ & $15.4 \pm 9.06$ \\
\hline General Surgery & $13(11.1 \%)$ & $\% 61.5$ & $37.2 \pm 15.18$ & $15.7 \pm 4.93$ & $15.6 \pm 8.11$ \\
\hline Hematology-Oncology & $9(7.7 \%)$ & $\% 55.5$ & $53.1 \pm 11.7$ & $15.7 \pm 5.23$ & $13.1 \pm 7.04$ \\
\hline Gynecology and Obstetrics & $9(7.7 \%)$ & $\% 62.5$ & $24.4 \pm 6.02$ & $14 \pm 2.78$ & $22.2 \pm 4.27$ \\
\hline Urology & $9(7.7 \%)$ & $\% 62.5$ & $40.3 \pm 12.53$ & $15.2 \pm 3.92$ & $17.5 \pm 7.64$ \\
\hline Cardiology & $7(6.0 \%)$ & $\% 71.4$ & $44.2 \pm 15.6$ & $15.2 \pm 3.59$ & $15.7 \pm 9.23$ \\
\hline Nephrology & $5(4.3 \%)$ & $\% 60$ & $49.4 \pm 15.53$ & $14 \pm 3.39$ & $9.7 \pm 11.1$ \\
\hline Ophthalmology & $5(4.3 \%)$ & $\% 80$ & $37.9 \pm 12.66$ & $17.2 \pm 3.71$ & $16.6 \pm 5.80$ \\
\hline Endocrinology & $4(3.4 \%)$ & $\% 75$ & $42.7 \pm 2.87$ & $15.7 \pm 12.66$ & $15.3 \pm 11.09$ \\
\hline Orthopedics & $2(1.7 \%)$ & $\% 100$ & $45 \pm 7.07$ & $32.5 \pm 28.917$ & $9.5 \pm 8.20$ \\
\hline Cardiovascular Surgery & $1(0.9 \%)$ & $\% 100$ & 52 & 24 & 7 \\
\hline
\end{tabular}

Table 4. Distribution of additional outpatient clinic visits.

\begin{tabular}{|c|c|c|}
\hline Visited outpatient clinics & $\begin{array}{l}\text { Number/Percentage of patients visiting } \\
\text { other outpatient clinics }\end{array}$ & $\begin{array}{l}\text { Number/Percentage of outpatient } \\
\text { clinic visits }\end{array}$ \\
\hline Psychiatry & $35(29.9 \%)$ & 167 (24.3\%) \\
\hline Physical therapy and rehabilitation / Rheumatology & $19(16.2 \%)$ & $32(4.6 \%)$ \\
\hline Neurology & $18(15.4 \%)$ & $44(6.4 \%)$ \\
\hline Cardiology & $15(12.5 \%)$ & $21(3.0 \%)$ \\
\hline Gastroenterology & $14(12 \%)$ & $16(2.3 \%)$ \\
\hline Cardiovascular Surgery & $12(10.3 \%)$ & $15(2.1 \%)$ \\
\hline Otorhinolaryngology & $11(9.4 \%)$ & $24(3.5 \%)$ \\
\hline Dermatology & $11(9.4 \%)$ & $23(3.3 \%)$ \\
\hline Orthopedics & $11(9.4 \%)$ & $17(2.4 \%)$ \\
\hline Hematology / Oncology & $10(8.5 \%)$ & $90(13.1 \%)$ \\
\hline General Surgery & $10(8.5 \%)$ & $26(3.7 \%)$ \\
\hline Ophthalmology & $10(8.5 \%)$ & $23(3.3 \%)$ \\
\hline Urology & $9(8.5 \%)$ & $34(4.9 \%)$ \\
\hline Nephrology & $8(6.8 \%)$ & $19(2.7 \%)$ \\
\hline Chest Diseases & $7(6 \%)$ & $20(2.9 \%)$ \\
\hline Endocrinology & $6(4.1 \%)$ & $7(1.0 \%)$ \\
\hline Infectious diseases & $5(4.3 \%)$ & $7(1.0 \%)$ \\
\hline Internal Medicine & $4(3.4 \%)$ & $24(3.5 \%)$ \\
\hline Gynecology and Obstetrics & $4(3.4 \%)$ & $22(3.2 \%)$ \\
\hline Algology & $4(3.4 \%)$ & $11(1.6 \%)$ \\
\hline Brain Surgery & $4(3.4 \%)$ & $9(1.3 \%)$ \\
\hline Plastic Surgery & $1(0.9 \%)$ & $2(0.2 \%)$ \\
\hline
\end{tabular}


a special subgroup of our study visited emergency department for 497 times during day and 262 times during night shifts.

The final diagnoses of the patients were determined and the most common diagnoses were grouped to determine the medical branches related to these diagnoses. According to this analysis, the distribution of the medical branches related to the most common diagnoses is shown in Tables 2 and 3.
The statistical analysis revealed that patients with chronic rheumatic pain and men suffering from pain visited emergency departments significantly more frequently $(p<0.05)$. Among patients visiting emergency departments for psychiatric reasons at least once in a year, after a suicide episode or for a chronic psychiatric disorder had a significantly higher rate of alcohol use $(p<0.05)$. In addition, elderly patients more commonly used alcohol $(p<0.05)$. Those with psychiatric disorders visited emergency departments more frequently than those without $(p<0.05)$.

Table 5. The list of chronic disorders of frequent patients.

\begin{tabular}{|c|c|c|c|c|c|c|}
\hline $\begin{array}{l}\text { Branch of Chronic } \\
\text { Disorder }\end{array}$ & Number/Percentage & & $M / F$ & $\begin{array}{l}\text { Mean number of } \\
\text { repeated visits }\end{array}$ & Mean frequency & Mean age \\
\hline Psychiatry & $37(31.6 \%)$ & $\begin{array}{l}\text { Schizophrenia } \mathrm{n}: 25 \\
\text { Anxiety disorder } \mathrm{n}: 7 \\
\text { Mood disorder } \mathrm{n}: 5\end{array}$ & $\% 70.2$ & $20.4 \pm 13.95$ & $15.3 \pm 7.83$ & $41.3 \pm 14.04$ \\
\hline $\begin{array}{l}\text { Physical therapy and } \\
\text { rehabilitation / } \\
\text { Rheumatology }\end{array}$ & $15(12.8 \%)$ & $\begin{array}{l}\text { Osteoarthritis/Disc Hernia n:12 } \\
\text { Rheumatic disorders: } \mathrm{n}: 3\end{array}$ & $\% 60$ & $22.7 \pm 19.87$ & $11.10 \pm 6.12$ & $40.9 \pm 7.06$ \\
\hline Cardiology & $14(12 \%)$ & $\begin{array}{l}\text { Hypertension: } 8 \\
\text { Chronic Heart Failure: } 4 \\
\text { Coronary Artery Disease: } 6\end{array}$ & $\% 64.2$ & $16.9 \pm 5.18$ & $13.7 \pm 7.56$ & $57.5 \pm 18.11$ \\
\hline Neurology & $13(11.1 \%)$ & $\begin{array}{l}\text { Chronic cerebrovascular disease n:6 } \\
\text { Epilepsy n:3 } \\
\text { Dementia-Alzheimer's n:4 }\end{array}$ & $\% 61.5$ & $17.2 \pm 4.41$ & $15.4 \pm 6.33$ & $52.3 \pm 22.54$ \\
\hline $\begin{array}{l}\text { Hematology / } \\
\text { Oncology }\end{array}$ & $13(11.1 \%)$ & $\begin{array}{l}\text { Hematologic malignancies: } 5 \\
\text { Oncologic malignancies: } 8\end{array}$ & $\% 61.5$ & $19 \pm 11.23$ & $11.2 \pm 5.91$ & $54.5 \pm 16.01$ \\
\hline Endocrinology & $11(9.4 \%)$ & $\begin{array}{l}\text { DM n:8 } \\
\text { Thyroid disorders n:5 }\end{array}$ & $\% 54.5$ & $17.7 \pm 5.21$ & $14.4 \pm 7.75$ & $47.0 \pm 16.97$ \\
\hline Nephrology & $10(8.5 \%)$ & CRF:10 & $\% 80$ & $15.2 \pm 5.00$ & $16.5 \pm 9.47$ & $53.9 \pm 16.18$ \\
\hline CVS & $6(5.1 \%)$ & Venous Insufficiency n:6 & $\% 33.3$ & $16 \pm 5.47$ & $9.9 \pm 8.00$ & $45.6 \pm 18.61$ \\
\hline Dermatology & $5(4.3 \%)$ & Chronic urticaria n:5 & $\% 83.3$ & $12.6 \pm 0.54$ & $15.4 \pm 10.13$ & $40.6 \pm 12.73$ \\
\hline Urology & $5(4.3 \%)$ & $\begin{array}{l}\text { Urolithiasis n:4 } \\
\text { Malignancy } \mathrm{n}: 1\end{array}$ & $\% 100$ & $15 \pm 5.19$ & $17.9 \pm 7.17$ & $41.2 \pm 8.87$ \\
\hline Ophthalmology & $3(2.6 \%)$ & Conjunctival diseases $n: 3$ & $\% 100$ & $19.6 \pm 6.65$ & $14.9 \pm 6.29$ & $50.6 \pm 10.01$ \\
\hline Gastroenterology & $3(2.6 \%)$ & Chronic Hepatitis n:3 & $\% 33.3$ & $14 \pm 1$ & $19.7 \pm 3.34$ & $45.3 \pm 2.08$ \\
\hline Chest diseases & $3(2.6 \%)$ & COPD n:3 & $\% 100$ & $15.3 \pm 3.05$ & $16.2 \pm 6.91$ & $55 \pm 17.57$ \\
\hline Infectious diseases & $2(1.7 \%)$ & Cellulitis n:2 & $\% 100$ & $14 \pm 0$ & $17.8 \pm 12.94$ & $55 \pm 14.14$ \\
\hline General Surgery & $1(0.9 \%)$ & Chronic hernia n:1 & $\% 100$ & 12 & 18.2 & 22 \\
\hline
\end{tabular}


The patients visited 8 different outpatient clinics other than emergency departments at least once. Patients visited $8(n=3), 7(n=2)$, and $6(n=1)$ different outpatient clinics, whereas 32 patients did not visit any other outpatient clinics. Detailed information about the use of outpatient clinics is given in Table 4.

The list of chronic disorders is shown in Table 5. Patients with chronic internal or hematological disorders had visited emergency departments significantly more frequently compared to other patients $(p<0.05)$. Patients with chronic nephrological or rheumatic disorders had a higher frequency of emergency department visits compared to patients with other chronic disorders $(p<0.05)$, although no significant increase in the number of repeated visits was detected. Only 3 female, and 1 male (\%3.4) patients a with a mean age of 27.5 years visited emergency departments after at least one suicide attempt during the study period.

Sixteen (9.9\%) patients died during the study period. These patients had a mean age of $57.9 \pm 15.3$ years with a median number of emergency department visits of 16.8, and a median interval of 15.7 days between emergency department visits. These patients, had hematologic-oncological disease ( $n=6: 37.5 \%)$, chronic psychiatric disease $(n=4: 25 \%)$, chronic cardiac disease $(n=3: 18.7 \%)$, and 2 (had nephrological disease $(n=2: 12.5 \%)$. Six out of 9 patients who died at our hospital died of oncological, and 3 of cardiac causes. The analysis of the deceased patients revealed that they had a significantly higher frequency of emergency department visits, significantly higher mean age, and significantly higher rates of chronic internal and oncological disorders $(p<0.05)$.

\section{DISCUSSION}

Frequent attenders in emergency departments are a major public health problem; although they visit emergency department frequently, they seem not to find any solution for their medical problems. In studies the patients considered to be frequent attenders made $\geq 12$ emergency department visits, that amount to $0.1 \%$ to $0.8 \%$ of the general emergency popu- lation and they were responsible for $0.8 \%$ to $5.4 \%$ of total visits to emergency departments ${ }^{9-12}$. The factors related to emergency health care policies and medical insurance systems of some countries and regions may be the underlying cause of such a high proportion of frequent attenders in emergency departments. We suggest that the large number of patients who visited emergency departments for 1-3 times finally made $\geq 12$ visits to the emergency departments that constituted $0.1 \%$ of the whole patient population, and being responsible for $1.3 \%$ of all emergency department visits. The findings of our study were in concordance with the literature in that men had a higher proportion among frequent attenders and the median age was around 40 years ${ }^{2,12-20}$. We did not detect any significant correlation between the number and frequency of emergency department visits and age or sex.

A limited number of studies specifically examining marital status of frequent attenders have shown that most of the patients were single $e^{9}$. In our study, the ratio of married patients was too low when compared to the ratio of married individuals in the general Turkish population, i.e. $63.9 \%$ according to Turkish Statistical Institute ${ }^{21}$.

According to a few studies examining the distance of a patient's residential addresses to emergency department ${ }^{9}$, most patients lived within 5 kilometers from emergency departments. Our study revealed that as distance from the hospital decreased the frequency of emergency visits and the number of frequent visits albeit non-significantly increased. The location of our hospital and the city plan of the city of Ankara indicates that our emergency department is $5-10 \mathrm{~km}$ away from centers of greater districts. This information may explain the discordance with literature data. It should be still emphasized that in accordance with literature data patients living closer to the hospital visited our emergency department more frequently.

On the other hand, another study analyzing the timing of emergency department visits in detail ${ }^{19}$, showed that emergency department visits became 
more frequent after normal office hours. In line with literature data, though not statistically significant our results found a positive correlation between visiting emergency department after normal office hours and being of older age and male. Despite the absence of any specific data in our study regarding this occurrence, we suggest that this discordance results from outpatient physicians referring patients to emergency departments before noon, after examining them in their office. Also, being in close vicinity to other district hospitals, and far from workplace areas where a large population lives during daytime, may be reason why our hospital is visited more frequently during morning hours. We suggest that this subject should be further studied.

In some studies, a significant proportion of frequent attenders present with exacerbations of preexisting disorders or complaints related to chronic disorders ${ }^{9,10,16,18,19,22}$. Studies have reported that the most common diagnoses at admission were injuries, sprains, UTIs, and abdominal pain, and that preexisting chronic psychiatric and internal disorders were the backgrounds of these diagnoses ${ }^{15,23}$. Although some former studies have stressed that frequent attenders commonly visit emergency departments after trauma, our study found a lower rate of trauma victims among frequent attenders. Like various studies in the literature, our study found that pain was the predominant admission complaint. Additionally, patients with hematological and oncological diseases constituted an important part of frequent attenders. Lack of training of frequent attenders about pain management provided by their primary and emergency physicians may give rise to frequent visits to emergency departments for pain. We believe certain strategies can be developed aiming at reducing emergency department visits for nonspecific complaints that can usually be managed by family physicians. Medico-social facilities can be built aiming at educating psychiatric patients and their families and provide them appropriate care to prevent emergency department visits.

Literature data indicate that elderly frequent atten- ders with chronic internal problems or young frequent attenders with psychiatric disorders have a higher mortality rate ${ }^{24}$. In our study the mortality rate of elderly patients with chronic oncological disease was high; however, no significant difference was found in the psychiatric patient group.

An analysis of patients presenting to emergency department with psychiatric problems indicated that the demographic and clinical properties of our population were in concordance with the literature ${ }^{25}$. In some studies, it was shown that at least one emergency department visit of frequent attenders was related to mental health, alcohol, or drug use; and frequent attenders had a significantly higher rate of mental or addiction-related problems than patients who visited emergency services less frequently ${ }^{26}$. Liu et al. ${ }^{12}$ reported that as the number of emergency department visits increased, the number of visits of psychiatric origin increased in parallel. According to our results, $35.6 \%$ of the patients presenting to emergency departments made at least one visit with a male predominancy. Besides, the number of visits increased among psychiatric cases than in non-psychiatric ones. It has been reported that drug addiction-related complaints have a significant proportion among causes of emergency department visits $^{11,16,24,27}$. Alcohol- and drug-related repeated visits had a low proportion to total emergency visits in our study believed to be due to cultural background of our country.

\section{Limitations of the study}

The main limitation of our study was related to our inability to obtain information about frequent attenders' visits to other emergency departments, hospital outpatient clinics, and family physician offices. This may have resulted in errors related to frequent visits to emergency departments, exclusion of patients who visited our hospital less frequently relative to other hospitals, and a failure to include frequent attenders who were under follow-up for internal and surgical disorders at other centers, but visited our hospital to receive emergency department service care. 


\section{CONCLUSION}

Frequent attenders constitute a frail population with complex problems, the solution of which should primarily lie in familiarizing with this patient population and defining their characteristics. Further studies will be beneficial for solving the problems of these patients. Emergency departments, public health centers, family physicians, ancillary healthcare staff, and social service officials should work in collaboration for the solution of this problem.

\section{REFERENCES}

1. Shih FY, Ma MH, Chen SC, Wang HP, Fang CC, Shyu RS, et al. ED overcrowding in Taiwan: facts and strategies. Am J Emerg Med. 1999;17(2):198-202. Epub 1999/04/02. PubMed PMID: 10102327. https://doi.org/10.1016/S0735-6757(99)90061-X

2. Byrne M, Murphy AW, Plunkett PK, McGee HM, Murray A, Bury G. Frequent attenders to an emergency department: a study of primary health care use, medical profile, and psychosocial characteristics. Ann Emerg Med. 2003;41(3):309-18. Epub 2003/02/28. S0196064402849915 [pii]. PubMed PMID: 12605196. https://doi.org/10.1067/mem.2003.68

3. Blank FS, Li H, Henneman PL, Smithline HA, Santoro JS, Provost $D$, et al. A descriptive study of heavy emergency department users at an academic emergency department reveals heavy ED users have better access to care than average users. J Emerg Nurs. 2005;31(2):139-44. Epub 2005/04/19. doi: S0099176705000607 [pii] 10.1016/j.jen.2005.02.008. PubMed PMID: 15834378.

4. Sandoval E, Smith S, Walter J, Schuman SA, Olson MP, Striefler $R$, et al. A comparison of frequent and infrequent visitors to an urban emergency department. J Emerg Med. 2010;38(2):11521. Epub 2008/05/09. S0736-4679(08)00026-7 [pii]. PubMed PMID: 18462906.

https://doi.org/10.1016/j.jemermed.2007.09.042

5. Kne T, Young R, Spillane L. Frequent ED users: patterns of use over time. Am J Emerg Med. 1998;16(7):648-52. Epub 1998/11/25. PubMed PMID: 9827738. https://doi.org/10.1016/S0735-6757(98)90166-8

6. Xu KT, Nelson BK, Berk S. The changing profile of patients who used emergency department services in the United States: 1996 to 2005. Ann Emerg Med. 2009;54(6):805-10 e1-7. Epub 2009/10/09. S0196-0644(09)01401-2 [pii]. PubMed PMID: 19811852.

https://doi.org/10.1016/j.annemergmed.2009.08.004

7. LeDuc K, Rosebrook H, Rannie M, Gao D. Pediatric emergency department recidivism: demographic characteristics and diagnostic predictors. J Emerg Nurs. 2006;32(2):131-8. Epub 2006/04/04. doi: S0099-1767(05)00718-X [pii] 10.1016/j. jen.2005.11.005. PubMed PMID: 16580475.

8. Rask KJ, Williams MV, McNagny SE, Parker RM, Baker DW. Ambulatory health care use by patients in a public hospital emergency department. J Gen Intern Med. 1998;13(9):61420. Epub 1998/10/01. PubMed PMID: 9754517; PubMed
Central PMCID: PMC1497017.

https://doi.org/10.1046/j.1525-1497.1998.00184.x

9. Althaus F, Stucki S, Guyot S, Trueb L, Moschetti K, Daeppen JB, et al. Characteristics of highly frequent users of a Swiss academic emergency department: a retrospective consecutive case series. Eur J Emerg Med. 2013;20(6):413-9. Epub 2013/01/23. PubMed PMID: 23337095.

https://doi.org/10.1097/MEJ.0b013e32835e078e

10. Moe J, Bailey AL, Oland R, Levesque L, Murray H. Defining, quantifying, and characterizing adult frequent users of a suburban Canadian emergency department. CJEM. 2013;15(0):113. Epub 2013/04/13. PubMed PMID: 23578730. https://doi.org/10.2310/8000.2013.130936

11. Doupe MB, Palatnick W, Day S, Chateau D, Soodeen RA, Burchill $C$, et al. Frequent users of emergency departments: developing standard definitions and defining prominent risk factors. Ann Emerg Med. 2012;60(1):24-32. Epub 2012/02/07. doi: 10.1016/j.annemergmed.2011.11.036 S0196-0644(11)01877-4 [pii]. PubMed PMID: 22305330.

12. Liu SW, Nagurney JT, Chang Y, Parry BA, Smulowitz P, Atlas SJ. Frequent ED users: are most visits for mental health, alcohol, and drug-related complaints? Am J Emerg Med. 2013;31(10):1512-5. Epub 2013/09/17. https://doi.org/10.1016/j.ajem.2013.08.006

13. LaCalle E, Rabin E. Frequent users of emergency departments: the myths, the data, and the policy implications. Ann Emerg Med. 2010;56(1):42-8. Epub 2010/03/30. https://doi.org/10.1016/j.annemergmed.2010.01.032

14. Martin GB, Stokes-Buzzelli SA, Peltzer-Jones JM, Schultz LR. Ten years of frequent users in an urban emergency department. West J Emerg Med. 2013;14(3):243-6. Epub 2013/05/21. PubMed PMID: 23687543; PubMed Central PMCID: PMC3656705. https://doi.org/10.5811/westjem.2012.5.11853

15. Lucas RH, Sanford SM. An analysis of frequent users of emergency care at an urban university hospital. Ann Emerg Med. 1998;32(5):563-8. Epub 1998/10/31. doi: S019606449800376X [pii]. PubMed PMID: 9795318.

16. Mandelberg JH, Kuhn RE, Kohn MA. Epidemiologic analysis of an urban, public emergency department's frequent users. Acad Emerg Med. 2000;7(6):637-46. Epub 2000/07/25. PubMed PMID: 10905642. https://doi.org/10.1111/j.1553-2712.2000.tb02037.x

17. Fuda KK, Immekus R. Frequent users of Massachusetts emergency departments: a statewide analysis. Ann Emerg Med. 2006;48(1):9-16. Epub 2006/06/20. doi: S01960644(06)00317-9[pii]10.1016/j.annemergmed.2006.03.001. PubMed PMID: 16781915.

18. Zuckerman S, Shen YC. Characteristics of occasional and frequent emergency department users: do insurance coverage and access to care matter? Med Care. 2004;42(2):176-82. Epub 2004/01/22. PubMed PMID: 14734955. https://doi.org/10.1097/01.mlr.0000108747.51198.41

19. Knowlton A, Weir BW, Hughes BS, Southerland RJ, Schultz $\mathrm{CW}$, Sarpatwari R, et al. Patient demographic and health factors associated with frequent use of emergency medical services in a midsized city. Acad Emerg Med. 2013;20(11):110111. Epub 2013/11/19. PubMed PMID: 24238312; PubMed Central PMCID: PMC4063348. https://doi.org/10.1111/acem.12253

20. Milbrett P, Halm M. Characteristics and predictors of frequent utilization of emergency services. J Emerg Nurs. 2009;35(3):191-8; quiz 273. Epub 2009/05/19. doi: 10.1016/j. jen.2008.04.032 S0099-1767(08)00258-4 [pii]. PubMed 
PMID: 19446122.

21. TUik. Turkey Statistical Year Book. 2014.

22. Lim SF, Wah W, Pasupathi Y, Yap S, Koh MS, Tan KL, et al. Frequent attenders to the ED: patients who present with repeated asthma exacerbations. Am J Emerg Med. 2014;32(8):895-9. Epub 2014/06/13. doi: 10.1016/j.ajem.2014.04.052 S07356757(14)00321-0 [pii]. PubMed PMID: 24919775.

23. Cook LJ, Knight S, Junkins EP, Jr., Mann NC, Dean JM, Olson LM. Repeat patients to the emergency department in a statewide database. Acad Emerg Med. 2004;11(3):256-63. Epub 2004/03/06. PubMed PMID: 15001405. https://doi.org/10.1197/j.aem.2003.10.023

24. Dent AW, Phillips GA, Chenhall AJ, McGregor LR. The heaviest repeat users of an inner city emergency department are not general practice patients. Emerg Med (Fremantle). 2003;15(4):322-9. Epub 2003/11/25. PubMed PMID: 14631698.

https://doi.org/10.1046/j.1442-2026.2003.00470.x
25. Vandyk AD, Harrison MB, VanDenKerkhof EG, Graham ID, Ross-White A. Frequent emergency department use by individuals seeking mental healthcare: a systematic search and review. Arch Psychiatr Nurs. 2013;27(4):171-8. Epub 2013/08/07. doi: 10.1016/j.apnu.2013.03.001 S08839417(13)00044-7 [pii]. PubMed PMID: 23915694.

26. Jelinek GA, Jiwa M, Gibson NP, Lynch AM. Frequent attenders at emergency departments: a linked-data population study of adult patients. Med J Aust. 2008;189(10):552-6. Epub 2008/11/18. doi: jel10469_fm [pii]. PubMed PMID: 19012551.

27. Minassian A, Vilke GM, Wilson MP. Frequent emergency department visits are more prevalent in psychiatric, alcohol abuse, and dual diagnosis conditions than in chronic viral illnesses such as hepatitis and human immunodeficiency virus. J Emerg Med. 2013;45(4):520-5. Epub 2013/07/13. doi: 10.1016/j.jemermed.2013.05.007 S0736-4679(13)00467-8 [pii]. PubMed PMID: 23845528. 